\title{
Status of ground water quality in selected areas of Ado-Ekiti, Nigeria
}

\author{
T. E. Dada ${ }^{1}$, E. E. Awokunmi ${ }^{1}$, C. R. Falegan ${ }^{2}$ \& E. O. Olanipekun ${ }^{1}$ \\ ${ }^{I}$ Department of Chemistry, University of Ado-Ekiti, Nigeria \\ ${ }^{2}$ Department of Microbiology, University of Ado-Ekiti, Nigeria
}

\begin{abstract}
Availability of clean and potable water is a great challenge to many people in Nigeria; hence groundwater is consumed in various parts of the country for domestic, agricultural, and other purposes. In this study, samples of water collected from hand-dug wells in selected areas of Ado-Ekiti (Nigeria) were subjected to some physicochemical and microbiological analyses with a view to assessing their suitability for drinking and other domestic applications. All the parameters were analyzed using standard procedures and results obtained were compared to standards prescribed by the World Health Organization (WHO) and the Nigerian Standard for Drinking Water Quality (NSDWQ). It was observed that samples collected from Orereowu area showed the highest values for bacterial counts (MPN), lead and cadmium, compared to samples from other areas. Despite that, samples from Olorunda area showed acceptable physicochemical parameters; however, the bacterial counts (MPN) exceeded the limits prescribed by WHO and NSDWQ, thus rendering them unfit for drinking purpose without pretreatment.
\end{abstract}

Keywords: groundwater, physicochemical parameters, coliforms, count, heavy, metals concentration, Nigeria.

\section{Introduction}

Water is essential for the survival of all living organisms. The quality of water is of vital importance for mankind since it is directly linked with human welfare [1]. Groundwater constitutes an important source of water supply for domestic supply and agriculture in Nigeria. The sedimentary basins generally form the best aquifers. Compared to the sedimentary aquifers, groundwater storage in the 
crystalline basement is small. The failure rate of new boreholes in the basement basin in some cases has been as high as $80 \%$ [2]. In large areas of the basement complex, the principal source of groundwater is from dug wells [3].

Groundwater is believed to be comparatively much cleaner and free from pollution than surface water. However, prolonged discharge of industrial effluents, domestic sewage and solid waste dump causes the groundwater to become polluted thus creating health problems [4]. The problems of groundwater quality are much more acute in areas which are densely populated, thickly industrialized and have shallow groundwater tables. Rapid urbanization has further affected groundwater quality due to exploitation of resources and improper waste disposal practices. Hence, there is always a need for concern over the protection and management of groundwater quality [5].

A number of groundwater quality investigations have been carried out in various parts of Nigeria [6-9]. The shallow aquifers of Nigeria are potentially vulnerable to pollution from agricultural (fertilizers), domestic (waste dumps, latrines) and industrial sources, except where surface layers are of poor permeability and afford some protection of the underlying aquifers.

Water-borne diseases are among the most recent emerging and re-emerging infectious diseases, which have recently proven to be the biggest health threat worldwide and they contribute $70-80 \%$ of health problems in developing countries. These diseases continue to be a major source of human mortality and morbidity [10].

Considering the health problems of groundwater contamination, the present study was carried out to investigate possible impact of the groundwater quality of hand-dug wells from selected areas in Ado-Ekiti, Nigeria. In this city, majority of the people rely on groundwater from hand-dug wells for various purposes due to non-availability of pipe-borne water. The aim of the study was to determine the suitability of the groundwater for drinking and other domestic applications by analyzing important physicochemical and microbiological parameters, and compare the same to limits prescribed by the World Health Organization (WHO) [11] and the Nigerian Standard for Drinking Water Quality (NSDWQ) [12].

\section{Experimental}

\subsection{Sample collection}

All the samples were collected in November and December 2009. The areas selected for the investigation are Orereowu (site1), Ajilosun (site 2) and Olorunda (site 3 ), as shown in fig. 1. The water samples were taken randomly from twelve hand-dug wells with average depths varying from 7 to $15 \mathrm{~m}$. All samples were collected in sterilized bottles, stored and transported in a cold box kept below $4^{\circ} \mathrm{C}$. Analyses were performed within 24 hours of collection. Samples for metal analysis were preserved by adding $3 \mathrm{ml}$ conc. nitric acid per litre of water, while those for dissolved oxygen were treated (as soon as 


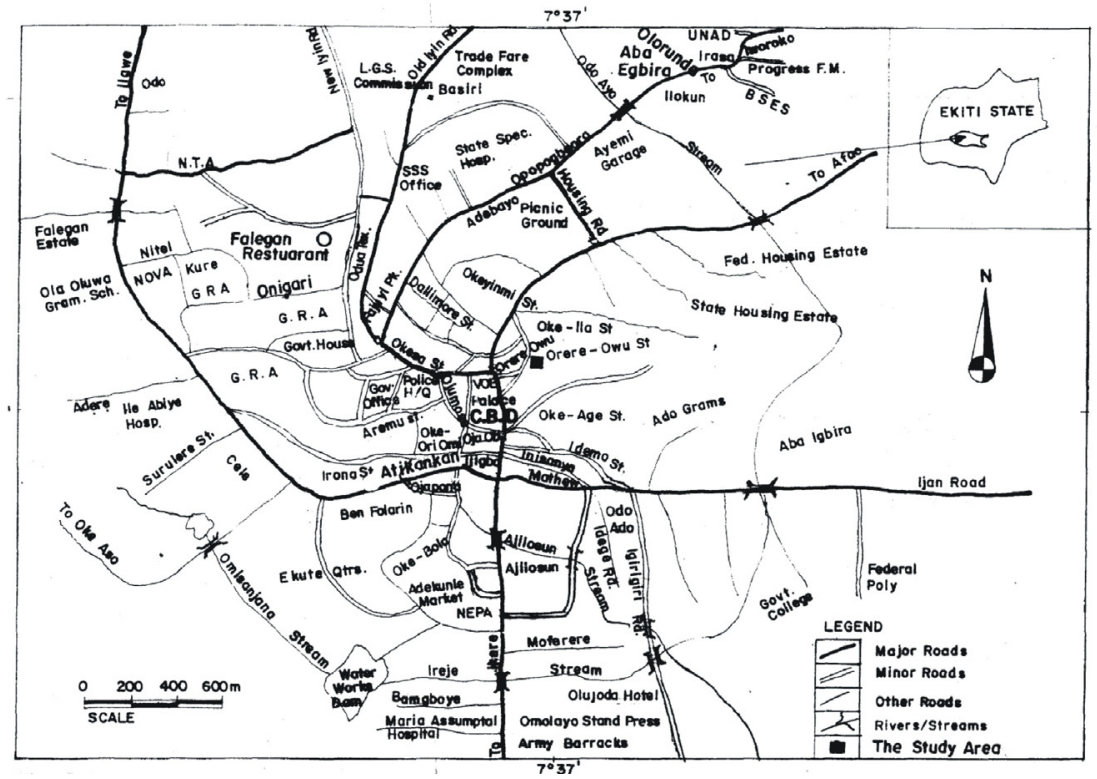

Figure 1: $\quad$ Sketch map of Ado-Ekiti showing the sampling locations.

collected) with $2 \mathrm{ml}$ of manganous sulphate and $2 \mathrm{ml}$ of alkaline-iodide-azide solutions.

\subsection{Physicochemical analyses}

All samples were analysed for $\mathrm{pH}$, electrical conductivity (EC), turbidity, total hardness (THD), calcium hardness (CHD), magnesium hardness (MHD), total dissolved solids (TDS), nitrate $\left(\mathrm{NO}_{3}{ }^{-}\right)$, sulphate $\left(\mathrm{SO}_{4}{ }^{2-}\right)$, phosphate $\left(\mathrm{PO}_{4}{ }^{3}\right)$, chloride $\left(\mathrm{Cl}^{-}\right)$, dissolved oxygen (DO), chemical oxygen demand (COD), temperature (temp.), cadmium $(\mathrm{Cd})$, copper $(\mathrm{Cu})$, and lead $(\mathrm{Pb})$, using standard procedures [13].

\subsection{Microbiological analysis}

Total coliforms in all samples were determined by the membrane filtration (MF) technique, as described by APHA [13].

\subsection{Statistical analysis}

Analysis of variance (ANOVA) and Pearson correlation coefficients were performed on the data using SPSS 17.0 for windows. 


\section{Results and discussion}

Table 1 shows the mean values of various water quality parameters obtained for samples at the three different locations selected for investigation: site 1 (Orereowu), site 2 (Ajilosun), and site 3 (Olorunda). The results are also graphically illustrated in figs. $2-5$.

Table 1: Mean values of water quality parameters for sample at different sites.

\begin{tabular}{|c|c|c|c|c|c|}
\hline \multirow[t]{2}{*}{ Parameter } & \multicolumn{3}{|c|}{ Mean \pm S.d } & \multicolumn{2}{|c|}{ Standard } \\
\hline & Site 1 & Site 2 & Site 3 & WHO & NSDWQ \\
\hline Temperature, ${ }^{\circ} \mathrm{C}$ & $29.2 \pm 1.3$ & $29.0 \pm 1.0$ & $28.8 \pm 0.8$ & - & Ambient \\
\hline $\mathrm{pH}$ & $7.16 \pm 0.11$ & $7.02 \pm 0.15$ & $7.30 \pm 0.16$ & $6.5-8.5$ & $6.5-8.5$ \\
\hline Turbidity, NTU & $5.46 \pm 0.44$ & $6.64 \pm 0.27$ & $4.50 \pm 0.41$ & 5.0 & 5.0 \\
\hline $\mathrm{EC}, \mu \mathrm{S} / \mathrm{cm}$ & $261 \pm 17$ & $188 \pm 16$ & $286 \pm 20$ & 1400 & 1000 \\
\hline $\mathrm{DO}, \mathrm{mg} / \mathrm{l}$ & $4.02 \pm 0.19$ & $6.20 \pm 0.21$ & $5.86 \pm 0.19$ & - & - \\
\hline $\mathrm{COD}, \mathrm{mg} / \mathrm{l}$ & $19.2 \pm 0.7$ & $9.1 \pm 0.5$ & $1.9 \pm 0.2$ & 255 & - \\
\hline TDS, mg/ 1 & $135 \pm 17$ & $111 \pm 15$ & $150 \pm 14$ & 1000 & 500 \\
\hline $\mathrm{THD}, \mathrm{mg} / \mathrm{l}$ & $92.6 \pm 5.3$ & $116.8 \pm 4.8$ & $110.6 \pm 3.7$ & 600 & - \\
\hline $\mathrm{CHD}, \mathrm{mg} / \mathrm{l}$ & $59.0 \pm 4.7$ & $77.8 \pm 6.2$ & $70.0 \pm 3.2$ & 75 & 150 \\
\hline $\mathrm{MHD}, \mathrm{mg} / \mathrm{l}$ & $33.6 \pm 2.1$ & $39.0 \pm 2.9$ & $40.6 \pm 3.4$ & 50 & - \\
\hline $\mathrm{NO}_{3}{ }^{-}, \mathrm{mg} / \mathrm{l}$ & $10.0 \pm 0.5$ & $9.0 \pm 0.8$ & $2.3 \pm 0.3$ & 10 & 50 \\
\hline $\mathrm{SO}_{4}{ }^{2-}, \mathrm{mg} / \mathrm{l}$ & $16.6 \pm 1.5$ & $18.9 \pm 1.5$ & $23.1 \pm 1.7$ & 400 & 100 \\
\hline $\mathrm{PO}_{4}{ }^{3-}, \mathrm{mg} / \mathrm{l}$ & $0.23 \pm 0.02$ & $0.20 \pm 0.01$ & $0.06 \pm 0.02$ & - & - \\
\hline $\mathrm{Cl}^{-}, \mathrm{mg} / \mathrm{l}$ & $15.2 \pm 1.0$ & $12.4 \pm 0.8$ & $5.7 \pm 0.7$ & 200 & 250 \\
\hline $\mathrm{Cd}, \mathrm{mg} / \mathrm{l}$ & $0.13 \pm 0.02$ & $0.11 \pm 0.01$ & N.d. & 0.005 & 0.003 \\
\hline $\mathrm{Cu}, \mathrm{mg} / \mathrm{l}$ & $0.23 \pm 0.02$ & $0.14 \pm 0.01$ & $0.07 \pm 0.01$ & 1 & 1 \\
\hline $\mathrm{Pb}, \mathrm{mg} / \mathrm{l}$ & $0.25 \pm 0.02$ & $0.20 \pm 0.02$ & N.d. & 0.05 & 0.01 \\
\hline $\begin{array}{c}\text { TC, MPN/ } \\
100 \mathrm{ml}\end{array}$ & $314 \pm 19$ & $75 \pm 8$ & $25 \pm 5$ & 0 & 10 \\
\hline
\end{tabular}

S.d. = Standard deviation; N.d. = Not detected.

Fig. 2 shows the mean values for temp., $\mathrm{pH}$, and $\mathrm{DO}$ at different sites. The temperature of water samples ranged from $28.8^{\circ} \mathrm{C}$ (site 3 ) to $29.2^{\circ} \mathrm{C}$ (site 1 ). The $\mathrm{pH}$ of samples varied between 7.02 and 7.30, for sites 2 and 3, respectively, and are within the acceptable limits of WHO and NSDWQ.

For turbidity, only site 3 had a value (4.50) that satisfies the limits prescribed by WHO and NSDWQ. The other two sites had slightly higher values than the permissible levels.

Threshold for DO is $5.0 \mathrm{mg} / \mathrm{l}$ for drinking water and very low DO values may result in anaerobic conditions that cause bad odours [14]. For the sites investigated, samples had DO values ranging from $4.02 \mathrm{mg} / \mathrm{l}$ (site1) to $6.20 \mathrm{mg} / \mathrm{l}$ (site 2). These values may not cause anaerobic conditions and this was probably a reason why the samples had no offensive odour. 


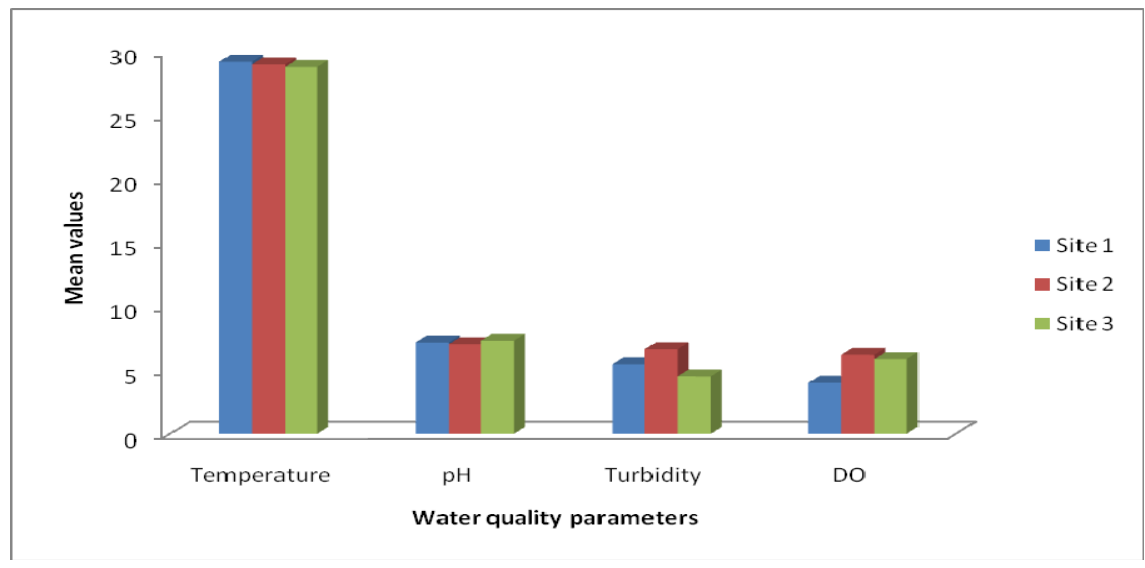

Figure 2: Mean values for temperature, turbidity, and dissolved oxygen at different sites. (fwv.)

The mean values for EC, TC, and TDS at different sites are presented in fig. 3. The EC values of water samples are quite below the maximum permissible levels given by WHO and NSDWQ, and ranged from 188 to $288 \mu \mathrm{S} / \mathrm{cm}$, for sites 2 and 3, respectively.

Coliform populations are indicators for pathogenic organisms and should not be present in drinking water. TC in samples ranged from $25 \mathrm{MPN} / 100 \mathrm{ml}$ (site 3) to $314 \mathrm{MPN} / 100 \mathrm{ml}$, implying that none of the sites conform to the acceptable standards. The very high TC values observed in site 1 was probably due to a preponderance of defecation/refuse sites, open-pit latrines in this area, which is inhabited mostly by illiterates and low-income earners.

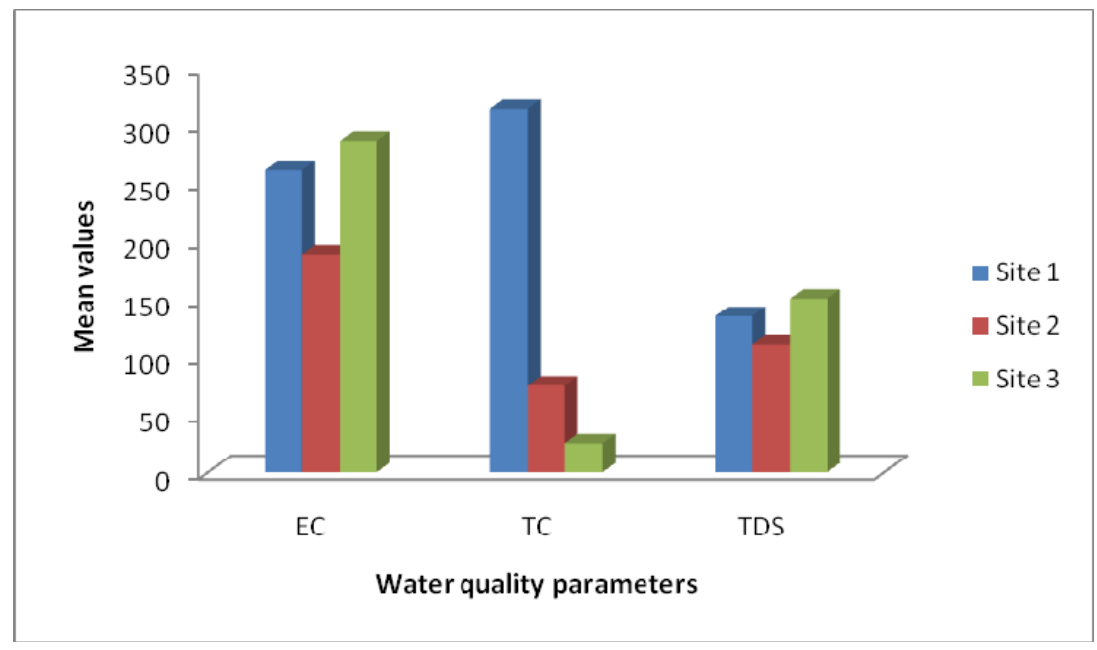

Figure 3: $\quad$ Mean values for EC, TC, and TDS at different sites. 
TDS values of samples ranged from 111-150 mg/l for sites 2 and 3, respectively, and are below the highest desirable limits set by WHO and NSDWQ. The high TDS values were probably responsible for the elevated EC values exhibited by the samples.

Fig. 4 illustrates the mean values for $\mathrm{NO}_{3}{ }^{-}$and $\mathrm{SO}_{4}{ }^{2-}$ concentrations, and COD at different sites. None of the samples investigated had a $\mathrm{NO}_{3}{ }^{-}$value that was higher than the permissible levels given by WHO and NSDWQ. $\mathrm{NO}_{3}^{-}$ concentration above $10 \mathrm{mg} / \mathrm{l}$ has been reported [15] to pose a serious health threat to pregnant women and infants below 6 months of age, because of its ability to cause methaemoglobinaemia or blue baby syndrome.

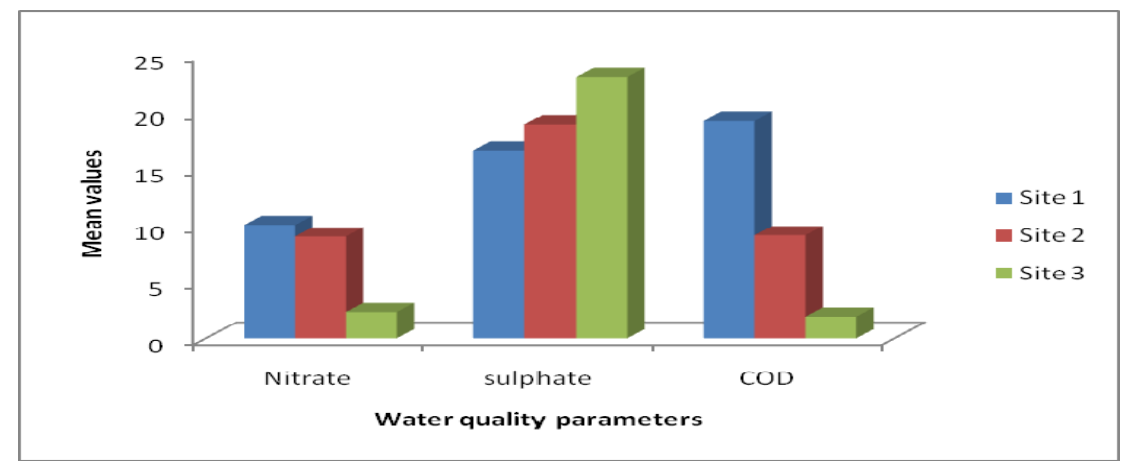

Figure 4: $\quad$ Mean values for nitrate, sulphate, and COD at different sites.

$\mathrm{SO}_{4}{ }^{2-}$ occurs naturally in water as a result of leaching from gypsum and other common minerals [16]. $\mathrm{SO}_{4}{ }^{2-}$ concentration in the samples varied between $16.6 \mathrm{mg} / 1$ for site 1 and $23.1 \mathrm{mg} / 1$ for site 3 , and are within the acceptable levels (WHO and NSDWQ).

COD is a measure of the amount of dissolved oxidizable organic matter, including the non-biodegradable matters [17]. Site 3 had a COD value of 1.9 $\mathrm{mg} / \mathrm{l}$, which is below $2.5 \mathrm{mg} / \mathrm{l}$ required of good drinking water. On the contrary, sites 1 and 2 had values which are far greater than $7.5 \mathrm{mg} / 1$ [18]; hence groundwater in both sites could be regarded as poor.

The mean values for $\mathrm{Cl}^{-}$concentration, THD, CHD, and MHD at different sites are indicated in fig. 5. The $\mathrm{Cl}^{-}$content of water samples ranged from $5.7 \mathrm{mg} / \mathrm{l}$ (site 3 ) to $15.2 \mathrm{mg} / \mathrm{l}$ (site 1 ). The observed values are quite below the maximum permissible levels set by WHO and NSDWQ.

THD and CHD values ranged from 92.6 to $116.8 \mathrm{mg} / \mathrm{l}$, and 59 to $77.8 \mathrm{mg} / \mathrm{l}$, for sites 1 and 2, respectively, while MHD values ranged from $33.6 \mathrm{mg} / 1$ for site 1 to $40.6 \mathrm{mg} / \mathrm{l}$ for site 3 . The observed THD and CHD values are generally within the acceptable limits of WHO and NSDWQ. The relatively higher values obtained in sites 2 and 3 were apparently due to the concrete rings in the wells unlike the wells in site 1 , the majority of which had no ring. 


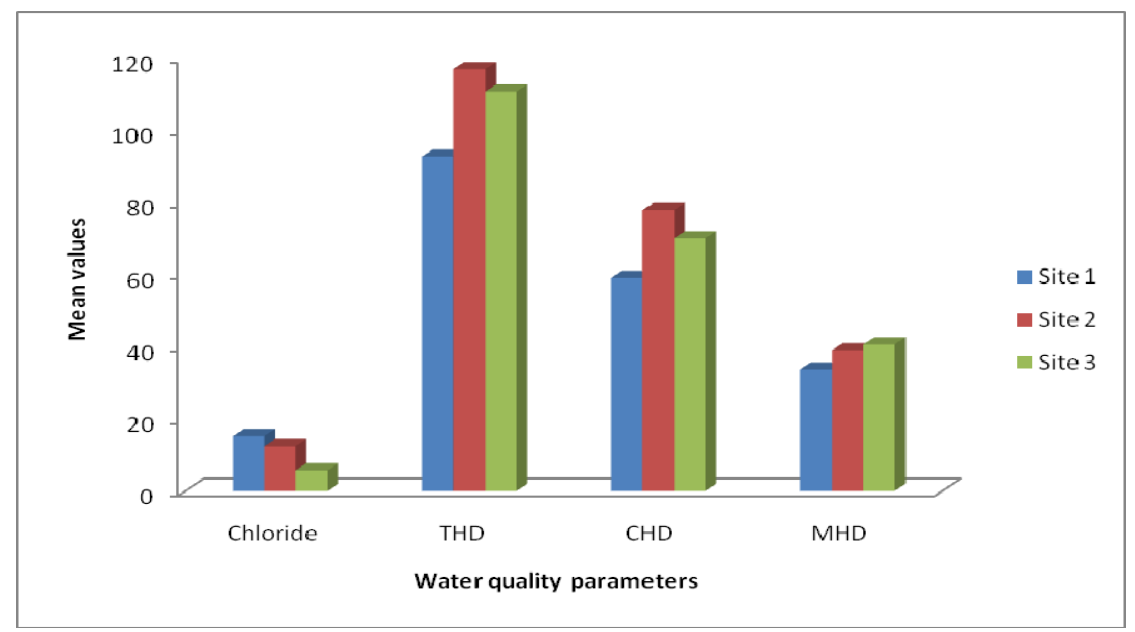

Figure 5: Mean values for chloride, THD, CHD, and MHD at different sites.

Fig. 6 shows the mean values for $\mathrm{PO}_{4}{ }^{3-}, \mathrm{Cd}, \mathrm{Cu}$, and $\mathrm{Pb}$ concentrations. $\mathrm{PO}_{4}{ }^{3-}$ may occur in groundwater as a result of discharge of domestic sewage, detergents, agricultural effluents with fertilizers, and industrial waste water [1]. Presence of phosphates in the samples, ranging from 0.06 to $0.23 \mathrm{mg} / \mathrm{l}$, for sites 3 and 1, respectively, may be principally due to discharge of domestic sewage and detergents. Traces of phosphates may increase the tendency of some algae to grow in water, hence are objectionable.

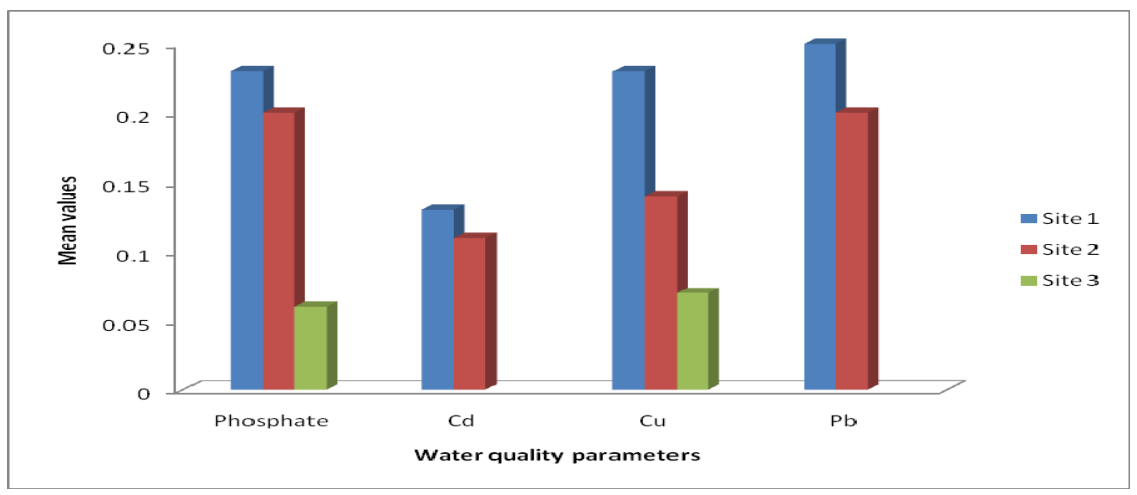

Figure 6: $\quad$ Mean values for phosphate, $\mathrm{Cd}, \mathrm{Cu}$, and $\mathrm{Pb}$ at different sites.

Concentration of $\mathrm{Cu}$ varied between $0.07 \mathrm{mg} / \mathrm{l}$ for site 3 and $0.23 \mathrm{mg} / \mathrm{l}$, for site 1 . These values conform to the limits of WHO and NSDWQ. Cd and Pb could not be detected in samples from site 3, whereas for sites 1 and 2, the observed values of 0.13 and $0.11 \mathrm{mg} / 1,0.25$ and $0.20 \mathrm{mg} / \mathrm{l}$, for $\mathrm{Cd}$ and $\mathrm{Pb}$, respectively, exceed the highest desirable levels prescribed by WHO and NSDWQ. Elevated concentrations of heavy metals in sites 1 and 2 could be 
attributed to anthropogenic activities from motor parks, auto-repair workshops, fuel stations, and refuse/dump sites located in both sites, but were absent in site 3 , which is a newly developed residential area.

Tables 2 and 3 show Pearson's correlation coefficients between different variables for site 1 where the groundwater exhibited the poorest quality. Significant correlations $(\mathrm{p}<0.05)$ were obtained between EC and TDS $(0.958)$, EC and COD (0.920), temp. and $\mathrm{PO}_{4}{ }^{3-}(-0.947)$, THD and CHD (0.920), TC and $\mathrm{Cd}(0.974), \mathrm{TC}$ and $\mathrm{SO}_{4}{ }^{2-}(0.983), \mathrm{Cd}$ and $\mathrm{DO}(0.914)$, and $\mathrm{NO}_{3}^{-}$and DO (-0.936).

Table 2: $\quad$ Correlation coefficients for different water quality parameters.

\begin{tabular}{|c|c|c|c|c|c|c|c|}
\hline Parameter & EC & TDS & COD & Temp & $\mathrm{PO}_{4}{ }^{3 \cdot}$ & THD & CHD \\
\hline EC & 1 & $0.958^{*}$ & $0.920^{*}$ & -0.648 & 0.497 & 0.405 & 0.577 \\
& & $(0.010)$ & $(0.027)$ & $(0.237)$ & $(0.395)$ & $(0.498)$ & $(0.309)$ \\
\hline TDS & $0.958^{*}$ & 1 & 0.801 & -0.466 & 0.295 & 0.585 & 0.664 \\
& $(0.010)$ & & $(0.103)$ & $(0.428)$ & $(0.630)$ & $(0.300)$ & $(0.221)$ \\
\hline COD & $0.920^{*}$ & 0.801 & 1 & -0.767 & 0.727 & 0.073 & 0.337 \\
& $(0.027)$ & $(0.103)$ & & $(0.130)$ & $(0.164)$ & $(0.908)$ & $(0.579)$ \\
\hline Temp & -0.648 & -0.466 & -0.767 & 1 & $-0.947^{*}$ & 0.378 & 0.204 \\
& $(0.237)$ & $(0.428)$ & $(0.130)$ & & $(0.014)$ & $(0.530)$ & $(0.742)$ \\
\hline $\mathrm{PO}^{3 \cdot}$ & 0.497 & 0.295 & 0.727 & $-0.947^{*}$ & 1 & -0.589 & -0.382 \\
& $(0.395)$ & $(0.630)$ & $(0.164)$ & $(0.014)$ & & $(0.296)$ & $(0.525)$ \\
\hline THD & 0.405 & 0.585 & 0.073 & 0.378 & -0.589 & 1 & $0.920^{*}$ \\
& $(0.498)$ & $(0.300)$ & $(0.908)$ & $(0.530)$ & $(0.296)$ & & $(0.027)$ \\
\hline CHD & 0.577 & 0.664 & 0.337 & 0.204 & -0.382 & $0.920^{*}$ & 1 \\
& $(0.309)$ & $(0.221)$ & $(0.579)$ & $(0.742)$ & $(0.525)$ & $(0.027)$ & \\
\hline
\end{tabular}

$*=$ Correlation is significant at the 0.05 level (2-tailed).

Table 3: Correlation coefficients for different water quality parameters.

\begin{tabular}{|c|c|c|c|c|c|c|c|}
\hline Parameter & $\mathrm{TC}$ & $\mathrm{SO}_{4}{ }^{2}$ & $\mathrm{NO}_{3}{ }^{*}$ & $\mathrm{DO}$ & $\mathrm{Cd}$ & $\mathrm{Cu}$ & $\mathrm{Pb}$ \\
\hline $\mathrm{TC}$ & 1 & $\begin{array}{c}0.983^{* *} \\
(0.003)\end{array}$ & $\begin{array}{c}-0.645 \\
(0.240)\end{array}$ & $\begin{array}{c}0.815 \\
(0.093)\end{array}$ & $\begin{array}{c}0.974^{*} \\
{ }^{*} \\
(0.005)\end{array}$ & $\begin{array}{c}-0.621 \\
(0.264)\end{array}$ & $\begin{array}{c}0.154 \\
(0.805)\end{array}$ \\
\hline $\mathrm{SO}_{4}{ }^{2-}$ & $0.983^{* *}$ & 1 & -0.580 & 0.727 & $0.938^{*}$ & -0.600 & 0.092 \\
& $(0.003)$ & & $(0.306)$ & $(0.164)$ & $(0.018)$ & $(0.285)$ & $(0.883)$ \\
\hline $\mathrm{NO}_{3}{ }^{*}$ & -0.645 & -0.580 & 1 & $-0.936^{*}$ & -0.793 & 0.073 & -0.790 \\
& $(0.240)$ & $(0.306)$ & & $(0.019)$ & $(0.109)$ & $(0.907)$ & $(0.112)$ \\
\hline $\mathrm{DO}$ & 0.815 & 0.727 & $-0.936^{*}$ & 1 & $0.914^{*}$ & -0.311 & 0.616 \\
& $(0.093)$ & $(0.164)$ & $(0.019)$ & & $(0.030)$ & $(0.610)$ & $(0.269)$ \\
\hline $\mathrm{Cd}$ & $0.974^{* *}$ & $0.938^{*}$ & -0.793 & $0.914^{*}$ & 1 & -0.555 & 0.320 \\
& $(0.005)$ & $(0.018)$ & $(0.109)$ & $(0.030)$ & & $(0.331)$ & $(0.599)$ \\
\hline $\mathrm{Cu}$ & -0.621 & -0.600 & 0.073 & -0.311 & -0.555 & 1 & 0.542 \\
& $(0.264)$ & $(0.285)$ & $(0.907)$ & $(0.610)$ & $(0.331)$ & & $(0.345)$ \\
\hline $\mathrm{Pb}$ & 0.154 & 0.092 & -0.790 & 0.616 & 0.320 & 0.542 & 1 \\
& $(0.805)$ & $(0.883)$ & $(0.112)$ & $(0.269)$ & $(0.599)$ & $(0.345)$ & \\
\hline
\end{tabular}

$*$ = Correlation is significant at the 0.05 level (2- tailed); ** = correlation is significant at the 0.01 level (2-tailed). 


\section{Conclusion and recommendations}

The physicochemical and microbiological analyses of groundwater from handdug wells at three different locations: Orereowu (site 1), Ajilosun (site 2) and Olorunda (site 3) in Ado-Ekiti, Nigeria, have revealed that comparatively, Olorunda had the best groundwater. However, presence of coliform populations in Olorunda groundwater renders the water unfit for drinking purpose without pre-treatment. In addition to high coliform populations observed for groundwater in Orereowu and Ajilosun, both sites exhibited higher values of $\mathrm{Cd}, \mathrm{Pb}, \mathrm{COD}$, and turbidity than acceptable standards (WHO and NSDWQ).The correlation coefficient data would be useful in selecting a proper treatment procedure to minimize groundwater pollution in the affected areas.

Since water-borne diseases largely occur as a result of contamination of water through improper disposal of domestic sewage and refuse, it is important that increased and sustained enlightenment programmes on public health and sanitation issues be held especially for people that depend on groundwater for drinking and other domestic purposes. Proper and effective waste disposal methods should be adopted by government, while efforts aimed at phasing out refuse/dump sites located around residential areas should commence in order to safeguard public health from water- borne diseases.

\section{References}

[1] Patil, V.T. \& Patil, P.R., Physicochemical analysis of selected groundwater samples of Amalner town in Jalgon District, Maharashtra, India. E- Journal of Chemistry, 7 (1), pp. 111- 116, 2010.

[2] Edet, A.E., Okereke, C.S., Teme, S.C. \& Esu, E.O., Application of remote sensing data to groundwater exploration: a case study of the Cross River State, South Eastern Hydrogeology Journal, 6, pp. 394- 404, 1998.

[3] Alagbe, S.A., Groundwater resources of River Kan Gimi Basin, NorthCentral Nigeria. Environmental Geology, 42, pp. 404-413, 2002.

[4] Raja, R.E., Sharmila, L., Merlin, J.P. \& Christopher, G., India J. of Environ. Protection, 22 (2), pp.137, 2002.

[5] Patil, P.R., Badgujar, S.R. \& Warke, A.M., Oriental J. of Chem. 17 (2), pp. 283, 2001.

[6] Adekunle, I.M., Adetunji, M.T., Gbadebo, A.M. \& Banjoko, O.B., Assessment of groundwater quality in a typical rural settlement in Southwest, Nigeria. Int. J. of Environ Res. and Public Health, 4(4), pp. 307318,2007

[7] Odeyemi, A.T. \& Olanipekun, E.O., Physicochemical and microbial analysis of water samples from some hand- dug wells in Iworoko Ekiti, Ekiti State, Nigeria. J. of Pure and Applied Microbiology, 1 (2), pp. 203206, 2007.

[8] Asubiojo, O.I., Nkono, N.A., Ogunsua, A.O., Oluwole, A.F., Ward, N.I., Akanle, O.A. \& Spyrou, N.M., Trace elements in drinking and groundwater 
samples in Southern Nigeria. The Science of the Total Environ., 208, pp. 18, 1997.

[9] Aremu, D.A., Olawuyi, T.F., Meshitsuka, S., Sridhar, M.K. \& Oluwande, P.A., Heavy metal analysis of groundwater from Warri, Nigeria. Int. J. of Environ. Health Res., 12, pp. 261- 267, 2002.

[10] Jahaya, B.L., Prasai, T., Singh, A. \& Yami, K.D., Assessment of drinking water of Madhyapur-Thimi and study of antibiotic sensitivity against bacterial isolates. Nepal J. Sci. Tech., 10, pp.162-172, 2009

[11] World Health Organization (WHO), Guidelines for Drinking Water Quality, Geneva, 1998.

[12] Standards Organization of Nigeria (SON), Nigerian Standard for Drinking Water Quality (NSDWQ), NIS 554: 2007, Lagos, Nigeria, pp. 15-19, 2007.

[13] APHA, Standard Methods for the Examination of Water and Wastewater. American Public Health Association, 20th edition, Washington D.C., 1998.

[14] Cruise, J.F. \& Miller, R.L., Interpreting the water quality of Mayaguez Bay, Puerto Rico using remote sensing, hydrologic modeling and coral reef productivity. Proc. of 2nd Thematic Conf. on Remote Sensing for Marine and Coastal Environments, New Orleans, LA, pp. 193- 203, 1994.

[15] Groen, J., Schumann, J.B. \& Gernaer, T.W., The occurrence of high nitrate concentration in groundwater in villages in Northwestern Burkinafaso. J. Afr. Earth Sci., 7 (7/8), pp.999- 1009, 1988

[16] Manivaskam, N., Physicochemical Examination of Water sewage and Industrial Effluent, 5th edition, Pragati Prakashan Meerut, 2005.

[17] Mahananda, M.R., Mohanty, B.P. \& Behera, N.R., Physicochemical analysis of surface and ground water of Bargarh District, Orissa, India. IJRRAS, 2(3), pp. 284-295, 2010.

[18] Esa, R., Drilled wells and groundwater in the Precambrian crystalline bedrock of Finland. Water Research Institute, Helsinki, Finland, 52, pp. 57, 1983. 